\section{Social Innovation in the Academic Curricula of Chemical Science Degrees in South Africa}

\author{
Pheladi Junior Mohlala and Jabulile Msimango-Galawe
}

\begin{abstract}
Social innovation is growing internationally and is a focus area for subSaharan Africa. While studies have been conducted on the factors that contribute to the failure to incorporate social innovation in academic curricula, there is a paucity of such research in the South African context, especially in relation to university curricula. This qualitative study explored chemical scientists' perceptions on the interventions required to introduce social innovation to the academic curricula of the chemical science degree in South African universities. Semi-structured interviews were conducted with I4 chemical scientists and the data was analysed using thematic analysis. The key findings included the overall lack of awareness and understanding of social innovation and the social challenges confronting South Africa. These factors hamper the development of sustainable academic curricula, effective community engagement and societal change. Furthermore, academic institutions' reluctance to embrace change is cause for concern.
\end{abstract}

Key words: Social innovation, chemical sciences, academic curriculum, South African universities

L'innovation sociale se développe à l'échelle internationale et constitue un domaine d'intérêt pour l'Afrique subsaharienne. Des études ont été menées sur les facteurs qui contribuent à l'absence d'intégration de l'innovation sociale dans les programmes scolaires ; ces recherches sont pourtant peu nombreuses dans le contexte sud-africain, plus particulièrement en ce qui concerne les programmes universitaires. Cette étude qualitative explore les perceptions des chimistes sur les interventions nécessaires pour introduire

ABOUt the AUthors: pheladi JUnior mohlala, Sasol Technology, South Africa. Email: pheladi.mohlala@sasol.com and JABULILE MSimANGo-GaLAWE, Wits Business School, South Africa. l'innovation sociale dans les programmes universitaires du diplôme en sciences chimiques dans les universités sud-africaines. Des entretiens semi-structurés ont été effectués avec I4 chimistes et les données ont été analysées à l'aide d'une analyse thématique. Parmi les principales conclusions figurent le manque général de sensibilisation et de compréhension de l'innovation sociale et les défis sociaux auxquels l'Afrique du Sud se trouve confrontée. Ces facteurs entravent l'élaboration de programmes d'études durables, l'engagement communautaire efficace et le changement sociétal. En outre, la réticence des établissements universitaires à accepter le changement est préoccupante.

Mots clés: innovation sociale, sciences chimiques, programme scolaire, universités sud-africaines

\section{Introduction}

While South Africa has witnessed many policy innovations since the transition to democracy in I994, the country still faces serious development challenges. Social innovation is a potential solution to these challenges.

The role of innovation in spheres of society other than economics has gained considerable interest (Andion et al., 20I7; Bersin and ChamorroPremuzic, 20I8). A body of specialised literature in this field is emerging (Phillips, Lee, Ghobadian, O’Regan, and James, 20I5), with social innovation considered a crucial issue in public policy (Sinclair and Baglioni, 20I4). Taylor (I970) defined social innovation as a practice-led field where people do things in a new way rather than learning about them academically. Blodgett, Melconian, and Peterson (20I5) note that social innovation takes on different forms in different environments, resulting in it being interpreted and defined in different ways. For example, it will differ in rural (Bock, 20ı6) and urban areas (Moulaert, Martinelli, González, and Swyngedouw, 2007), as the social context and needs will be different. Murray, Mulgan, and Caulier-Grice (2008) state that, because it cuts across different industries and fields of practice, social innovation is multidisciplinary in nature. This has also contributed to the diverse meanings and uses of the term (van der Have and Rubalcaba, 20I6). It has been applied in terms of social enterprise and social entrepreneurship, socially beneficial technological innovations, corporate social responsibility, and open innovation (Dees and Anderson, 2006).

Over the past decade, increasing interest has been shown in social entrepreneurship throughout the world as a means of achieving sustainable economic growth (Daud et al., 20I8). In the United States, former President Barack Obama launched the Social Innovation Fund, which provides grants to intermediaries who identify and fund promising programmes 
(Phills, Deiglmeier, and Miller, 2008). In South Korea, Seoul Mayor Park Won-Soon is incorporating approaches to social innovation into city government (Kim, Rim, Han, and Park, 20I5). The European Commission has established guidelines to encourage and extend social development across Europe (Atkinson and Da Voudi, 2000). In Japan, social innovation is rapidly taking root in reconstruction efforts following the 20II tsunami and nuclear disaster which devastated the country's physical, cultural, and socio-political landscape (Matanle, 20II).

As a nation, South Africa is in dire need of fundamental social, economic, and cultural transformation (Oosthuizen, 20I6). The traditional model of government support is insufficient to meet the challenges (Gelb, 2006) and creative and innovative approaches are required to foster sustainable growth, secure jobs, and improve competitiveness (Van Niekerk and Viviers, 20I4).

While the I996 White Paper on Science and Technology (Department of Arts, Culture, Science and Technology, I996) endorsed social innovation, it was not consciously applied or promoted outside the political arena (Hart, Ramoroka, Jacobs, and Letty, 20I5). Furthermore, notions of what social innovation should include range from social welfare benefits, to public goods, and a primary focus on disadvantaged members of society (Hart et al., 20I5). More recently, the focus has shifted to sustainable growth that supports disadvantaged community members as innovators and integrates social and economic development elements (Baker and Mehmood, 20I5). While confusion persists with regard to terminology, evidence suggests that community actors are engaged in various forms of social innovation in South Africa's rural areas despite limited government involvement that is exacerbated by institutional constraints, and poor understanding of contemporary ideas around innovation and social innovation (Mulder et al., 2008). In most cases, the goal is to improve the social and economic wellbeing of the poor (Patel and Hochfeld, 2013).

As the following examples illustrate, social innovation is being put into practice and delivering the desired results in finance, agriculture, government, and higher education institutions (HEIs)in different countries.

Microfinance is a form of social innovation that provides financial services to low-income clients, including those who are self-employed as a means of poverty alleviation (Armendàriz and Morduch 2005). Another example of social innovation is Fair Trade Products, a trading partnership that promotes greater equality in international trade based on dialogue, transparency and respect. It contributes to sustainable development by providing improved trade conditions for marginalised producers and workers, especially in the Global South (Raynolds and Wilkinson 2007; Moore 2004; Nicholls and Opal 2005).

Transformative social innovation in Indian agriculture includes the
System of Rice Intensification (SRI) developed by Prasad (20I6). Through this initiative, farmers in India reclaimed control of their livelihoods. Vulnerable communities participate in collective exploration, action, and adaptation. Indian agriculture has been associated with deskilling, agricultural individualisation, and a high suicide rate.

In Europe, the Transformation Towns Network (TTN), which emerged in small towns like Totnes and has since expanded to larger cities, is proof of growing interest in social innovation (Aiken, 2012). It's approach to socioecological systems focuses on permaculture linked to Resilience Thinking (Walker and Salt 2006) and places the community at its core. The network is a good example of the rise and character of 'community' responses to climate change and the campaign to reduce carbon emissions.

Social innovation initiatives in Seoul, South Korea have led to Sustainable Metropolitan Governance (SMG). Seoul has improved its residents' quality of life by introducing social innovation programmes that have made the city more competitive at the global scale. A variety of creative ideas, including providing free Wi-Fi in the city to make the Internet easily accessible (O'Byrne et al., 20I4) have encouraged citizens to engage more with fellow citizens, especially educators, through on and off-line interactions. An Internet Addiction Prevention Education programme, which focuses on students, teachers, and parents, was also introduced.

The iShack initiative in Stellenbosch, South Africa, is a social innovation initiative that upgraded informal settlements as opposed to relocation. A group of postgraduate students at Stellenbosch University engaged with the community and designed social and system innovation responses to water scarcity, land grabbing, soil degradation, slum urbanism, energy poverty, and food insecurity (Swilling, 20I6). What started as a relatively small technological intervention developed into a larger community-based social innovation process.

It is against this background that our study investigated the possibility of integrating similar forms of social innovation into the chemical science curriculum for the benefit of communities.

Social innovation is a multidisciplinary field that involves a broad range of activities, including non-profit and social enterprise programmes (Brock and Steiner, 2009), social development initiatives (Sekliuckiene and Kisielius, 20I5), facilities, and corporate social responsibility practices (Rexhepi, Kurtishi, and Bexheti, 20I3). This calls for specific academic competencies, and personal and managerial skills to develop sustainable models that ensure consistent community engagement, and the necessary change.

It has been more than two decades since the end of apartheid and South Africa's first democratic elections. On taking up office in I994, the African National Congress government committed to the social, economic, and 
political transformation and development of South Africa, and to address the legacies and imbalances of the apartheid system. However, progress has been mixed. South Africa remains one of the world's most unequal countries, scoring 63.4 on the Gini index (Sulla and Zikhali, 20I8). Although declining, poverty levels remain stubbornly high, with $31 \%$ of the population living below the national poverty line (Central Intelligence Agency World Fact Book, 20I4). Creative and innovative solutions are thus required to promote sustainable growth, secure jobs, and increase the country's competitiveness.

Social innovation aims to respond to a variety of challenges, including scarce resources and a lack of innovative thinking (McGowan and Westley, 20I5). Disruptive social change is not a new phenomenon, but one that has been experienced throughout human history. Finegold and Notabartolo (20I0) state that in the twenty-first century, education will be the foundation of material as well as intellectual progress. They add that the challenge is to develop an educational system that responds to the economic and social demands of this century and fosters innovative capabilities that will spread throughout the population. Universities are well-placed to respond to this need by embedding social innovation and entrepreneurship in their curricula. This would assist in narrowing the gap between the theoretical and practical aspects of these approaches.

Chemical scientists' development is one of the least explored topics in scientific studies and theory (Levine, 20I8). However, the literature notes that scientists generally lack business acumen and social innovation. This study examined the possibility of integrating social innovation in South African universities' chemical science curricula. It thus adds to the body of knowledge that supports combination degrees in chemical science and social innovation as an integrative approach to scientists' development that is flexible and agile. While acknowledging the difficulties and complexities of the South African economy (Rodriguez and Rodriguez, 20I5), the study also adds to the literature by examining chemical scientists' experiences of social innovation and investigating what could be added to the usual science degree offerings to enhance their professional success. It thus offers an understanding of how social innovation could impact the curricula of chemical science degrees (Galego, Soto, Carrasco, Amorim, and Ferreira Dias, 20I8b). In particular, it lays the foundation for the development of a theoretical framework to explain the impact of social innovation education on chemical scientists by examining it from the participants' perspectives.

The results of the study will benefit chemical industries, as they require employees that have scientific training as well as skills in social innovation. Universities will also gain insights from the views of chemical scientists on how social innovation could impact the careers of such scientists. Finally, chemical science students will gain by developing an understanding of how social innovation can be used to address the social challenges confronting South Africa, thus preparing them for a globally competitive science future.

At the national level, the government is seeking ways to reduce unemployment (Omarjee, 20I9). A workforce with a degree in chemical sciences and social innovation could be used as leverage in this regard. The unique attribute of such a combination degree is that it provides the individual with flexibility and ability to adapt quickly to economic changes (Baxter, 2009).

The study did not aim to assess all the professions in chemical sciences, but only the careers of science in chemistry. For the purpose of this study, the term 'scientist' refers to a professional with a chemistry degree (Kovac, 20I8). Given the large number of prospective research participants, the population for this study was restricted to chemistry graduates from different universities in South Africa, but not all universities, as well as academics from the department of chemistry and employees in chemical industries. It is assumed that the participants responded honestly and factually to the interview questions, as it would take significant time and effort to validate each participant's responses. To promote honesty, the participants were assigned pseudonyms and confidentiality was protected through a confidentiality agreement.

The study's objective was to explore chemical scientists' perceptions of the interventions required to introduce social innovation to the academic curricula of the chemical science degree in South African universities. The primary research questions were: (I) What do chemical scientists perceive as necessary interventions to introduce social innovation to the academic curricula of the chemical science degree in South African universities? (2) How would social innovation enhance the academic curricula of the chemical science degree at South African universities? (3) What are the barriers to the introduction of social innovation in the field of chemical sciences in South African universities? (4) What impact could a chemical sciencesocial innovation degree have on the careers of chemical scientists?

Data were gathered by means of semi-structured interviews with chemical science graduates including academic staff members, individuals working in chemical industries, and current postgraduate students.

\section{Literature review}

Social innovation in academic curricula

The education system, especially basic and higher education in South Africa, has been considered as slow in responding to the need for social and economic development (Spaull, 2013). Higher education institutions have processes in place for regular curriculum renewal and these are usually in line with each institution's mission and profile. An effective curriculum should be driven by student needs, the mission of the institution and 
programme, discipline standards, and partners' needs. To ensure that core skills and knowledge are covered, key stakeholders should be involved in curriculum development.

Scholars argue that universities should embed social innovation and entrepreneurship in their curricula (Kummitha and Majumdar, 20I5) in order to address the gaps between the theoretical and practical aspects of a discipline (Alden Rivers, Armellini, Maxwell, Allen, and Durkin, 20I5). Universities have demonstrated extraordinary resilience as organisations and have proven that they are able to change and adapt (Sporn, I999). However, modern universities confront a variety of challenges. A common thread that characterises many of these problems is the interaction between universities and market forces (Leydesdorff and Etzkowitz, 200I). Finegold and Notabartolo (2010) state that the challenge is to establish an educational system that responds to future economic and social demands as well as the spread of technological capabilities across the population.

Academic curricula enhanced through social innovation The development of new curricula in academic institutions

While today's world is changing faster than at any point in history (Cukier and Mayer-Schoenberger, 2013), few changes have been made to undergraduate degrees (Tomlinson, 20I7). The Institute for the Future forecasts that $85 \%$ of jobs that will exist in 2030 have not yet been created (Tencer, 20I7). Brougham and Haar (20I8) note that it is difficult for academic staff to understand the impact of the rapidly changing workplace on students' future career prospects when so little has changed in how universities function. The question that arises is, how can students be better prepared for a future that cannot be predicted in a world that is rapidly changing? Traditional education lays the foundation for technical knowledge, but given the rapid pace of change, this is not sufficient.

The modern labour market demands entrepreneurial, dynamic problemsolving skills, creativity, and cognitive flexibility (World Economic Forum (20I6). The current generation needs to learn new ways of working and this can be achieved by offering them opportunities to shape their future (Rainie and Anderson, 20I7). Some will start their own businesses, while for those that are employed, these skills and perspectives will enable them to change the way the organisations that employ them operate.

It is not certain how universities will prepare students for the uncertain future ahead (de Villiers Scheepers, Barnes, Clements, and Stubbs, 20I8). Moreover, it is not apparent if traditional teaching methods and degree courses will continue to exist or will become part of a diverse learning environment (Fry, Ketteridge, and Marshall, 2008). While there is no single solution, it is clear that universities will need to embrace new ways of working to remain relevant.
Windeløv-Lidzélius (20I8) highlights that it is not simply a matter of adopting new technology, but about rethinking the role of the lecturer, as well as what happens in the classroom and the relevant academic methods. This implies that academic institutions should co-create education with students (Bergmark and Westman, 20I6). Davey et al. (20I8) emphasise that academic models need to shift from teaching to facilitating and leading through social innovation. However, this requires a new mindset and skills set. Field (2000) observes that, if the future of education is lifelong learning, it should go beyond institutional walls to the societies in which academic institutions are situated.

The development of new competencies and skills in academic institutions Universities are increasingly criticised by their stakeholders for not responding to the skills needs of modern economies (Tremblay, Lalancette, and Roseveare, 20I2). Disagreements and tension, including conflict between educational institutions and businesses about what kind of knowledge and skills students bring to the labour market are not new and contribute to productive dialogue (Ruben, 20I8). However, in the current situation, tensions have accumulated and could become explosive. An example is multinational consulting company Ernst and Young's public announcement in 2015 that it would no longer look at university credentials when hiring talent, as there was "no evidence that success at university correlates with achievement later in life" (Davey et al., 2018). Universities do relatively well in translating changes in scientific knowledge into course content, but they do not recognise equally significant changes in the demand for skills in the outside world, particularly in the societies they operate in, and transform their education programmes accordingly (Fry et al., 2008). The complex and unpredictable shifts in demand for skills will increase the importance of those such as higher-order cognitive skills, complex communication skills, and emotional skills (Bughin et al., 2018). Most universities have yet to acknowledge that such skills should no longer only be required of researchers and academics, but should be part of all university education.

While some universities have taken heed of employer-driven demands (Sharma, 20I7), the question is whether this will be sufficient to change societies and impact current economies? Universities should be able to address the skills development needs of economies and communities that are highly volatile and unpredictable (Reddy, Bhorat, Powell, Visser, and Arends, 20I6). Employees should be able to work with communities and interdisciplinary groups (Nancarrow et al., 2013). They should be able to understand and creatively solve the problems faced by their societies and be eager to learn. 
Proposition I: Social innovation enhances the academic curricula of chemical science degrees in South African universities.

Barriers to social innovation in academic curricula

Discussion in government forums in South Africa has not focused on social entrepreneurship and the quality of life (Littlewood and Holt, 20I8). However, the economic crisis has resulted in a growing number of social entrepreneurship initiatives in the country (Manyaka, 20I5) in the form of small, medium, and micro enterprises (SMMEs) (Mabotja, 20I9). This was also the case in Latin America, where Galego, Amorim, Dias, and Sarmento (20I8a) noted that the economic crisis led to the adoption of social innovation to create jobs for the youth.

South African universities have undergone structural changes and mergers to promote equity, quality, development, efficiency, and effectiveness (Hay and Fourie, 2002). However, much remains to be done to create a new identity as inclusive and equitable institutions (Mabokela, 2003).

Proposition 2: Universities in South Africa confront barriers to the integration of social innovation in the chemical science field.

Integration of the chemical science degree and social innovation

Sustainable, practical and affordable solutions are required to address the social and environmental issues confronting the world (Matus, Clark, Anastas, and Zimmerman, 20I2; Melles, de Vere, and Misic, 20II). Scientific and technological innovation continues to play a key role in catalysing new industries, spawning job growth (Ayres, I996), and improving the quality of life of people around the world (Shuzi, 2002). In many respects, improving the quality of life in South Africa through technological innovation has been taken for granted (Walwyn and Cloete, 20I8).

Scientific innovation has contributed to many of the greatest social achievements in human history (Núñez Jover and López Cerezo, 2008). These include, but are not limited to, chlorination of drinking water (Masri, I986), oral rehydration therapy (Santosham, 2002), solar energy (McEachern and Hanson, 2008), pasteurisation (Mújica-Paz, Valdez-Fragoso, Samson, Welti-Chanes, and Torres, 20II), and many other technological innovations. It is thus evident that science-based and technology-based approaches are integral to meet societal needs. In order to create a path for social innovation, scientists and engineers must find ways to build paths for potential innovators (Lettice and Parekh, 2010).

It is clear that science has shaped almost every domain of social life, leading to what is known as the rise of the knowledge society. However, if science is overwhelmingly shaping society, why shouldn't society also shape science? Why should scientists' 'own selection of research topics' go unchallenged? Should society not assert its priorities? The problem may be familiar, but new circumstances mean that it cannot be solved using the same formula. Social participation is called for where social transformation is driven by science. Embracing social innovation as part of their social responsibility would enable South African universities to work as a force for good in society.

Proposition 3: An integrated chemical science with social innovation degree will have a significant effect on the careers of chemical scientists.

\section{Methodology and procedures}

Research approach

An exploratory and descriptive qualitative research method was employed to investigate scientists with chemical science degrees' perceptions of the interventions required to introduce social innovation to the chemical science degree curriculum in South Africa. This method was chosen due to its flexibility in enabling an exploration of the experiences of others (Miles, Huberman, and Saldaña, 20I4). The exploratory approach was selected to gain new perspectives and unearth new concepts with regard to increasing social innovation awareness throughout academic curricula.

\section{Sampling}

A purposive sampling technique was employed. According to (Omona, 2013), a purposeful sample enhances the quality of data obtained, thereby promoting reliability. Careful thought was given to who would be invited to participate in order to ensure representation of a wide range of experiences. Data were gathered from three different groups of participants, namely, chemical science lecturers; chemical science postgraduate students; and scientists working in the chemical industry. The sample consisted of I4 participants.

\section{Data collection}

A questionnaire was administered to the participants, followed by faceto-face semi-structured interviews to obtain their opinions and views on the phenomena under review. A letter was attached to the questionnaires outlining the purpose of the study as well as a letter of consent. The participants were assured that their privacy and anonymity would be maintained. An interview schedule was used to promote higher level understanding and explanation (Kvale and Flick, 2007). The interview approach also helps to break down and simplify complicated answers. Each interview lasted 35 to 45 minutes. A digital recorder was used and the researcher also took notes during the interviews. 


\section{Research instrument}

The qualitative interviews enabled in-depth information to be collected on the research topic. Therefore, a limited number of questions were posed in order to enable the participant to have time to talk at length. A list of openended questions was composed with no numbering, so that the questions were not asked in the order they were listed, enabling them to fit easily into the interview. The interview started with small talk that evolved into asking a neutral question that invited the participants to describe something related to the topic. All aspects of the participants' experience with and perspectives of the topic were addressed. The interview questions were subdivided into four sections:

Part I focused on general information. The three questions (QI-3) identified the universities attended by the scientist and his/her primary reasons for studying chemical sciences. The type of work currently done by the scientist was also identified.

Part 2 (Q4 and 5) focused on the scientists' practical knowledge of social innovation and examples of social innovation initiatives in their day-to-day work. The goal was to enable them to share their own experiences of social innovation in their careers.

Part 3 (Q6-8) solicited the scientists' views on social innovation and if they felt it would improve the academic curriculum of a degree in chemistry at universities in South Africa. The aim was to encourage scientists to share their thoughts on social innovation and their future careers.

Part 4 (Q9) contained a question on the scientists' perceptions of the steps that universities should take to introduce the social innovation content required to address socio-economic challenges in South Africa.

\section{Data analysis and interpretation}

Thematic content analysis was used to analyse the transcribed data and identify common themes. The interviews were translated and transcribed. The researchers then read and re-read the interviews, reflecting on them as a whole. Castleberry and Nolen (20I8) state that a researcher should then summarise the interviews, bearing in mind that in a series of interviews, there could be more than one theme. Once defined, the themes that seemed to be important concepts were recorded.

The questions posed to the participants were used to formulate codes derived from the answers, which were further categorised to formulate themes. According to Leedy and Ormrod (2005), qualitative data analysis involves reading transcripts, developing codes, coding data, and drawing links between discrete pieces of data.

\section{Results and discussion}

The findings presented and discussed here are the results of the thematic content analysis of the interview data. The aim was to understand scientists with chemical science degrees' perceptions of the interventions required to introduce social innovation to the chemical science curriculum in South Africa. The themes and categories that emerged during data analysis are summarised in Figures I and 2. Each category yielded several themes that are discussed in more detail following the figures. The top theme per category (see Figure 2) is discussed, followed by proposed interventions.

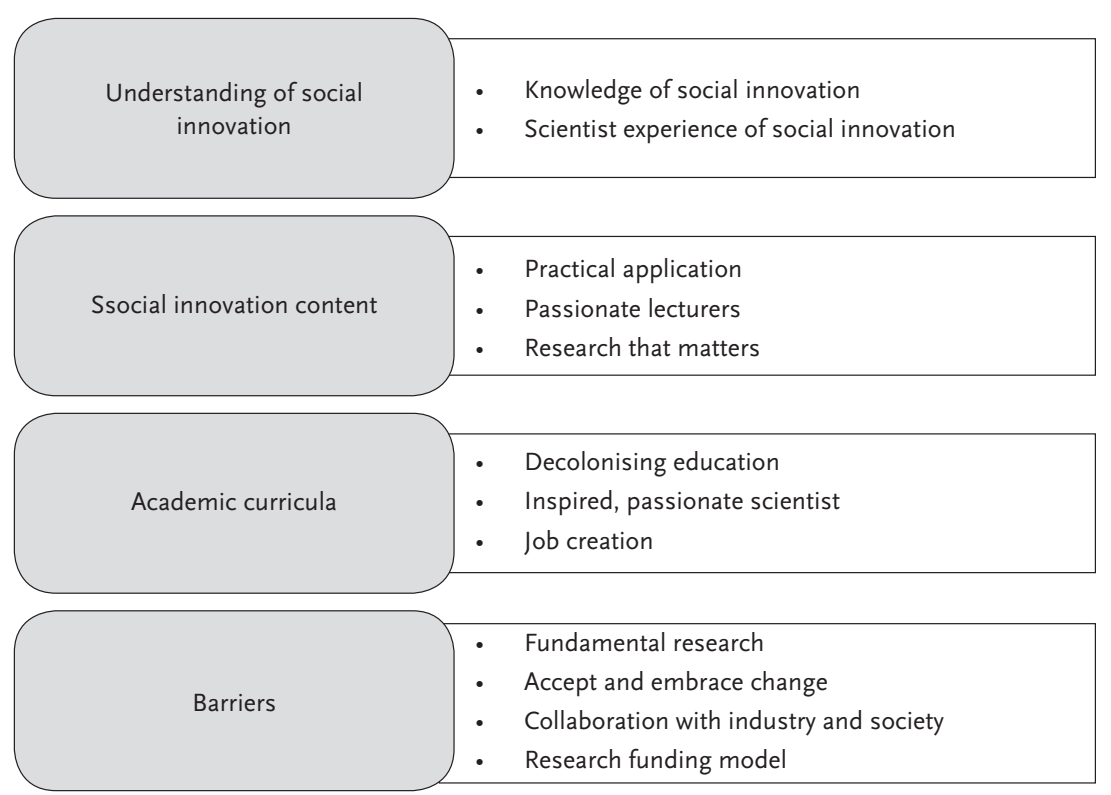

Figure 1: Themes relating to the four social innovation categories 


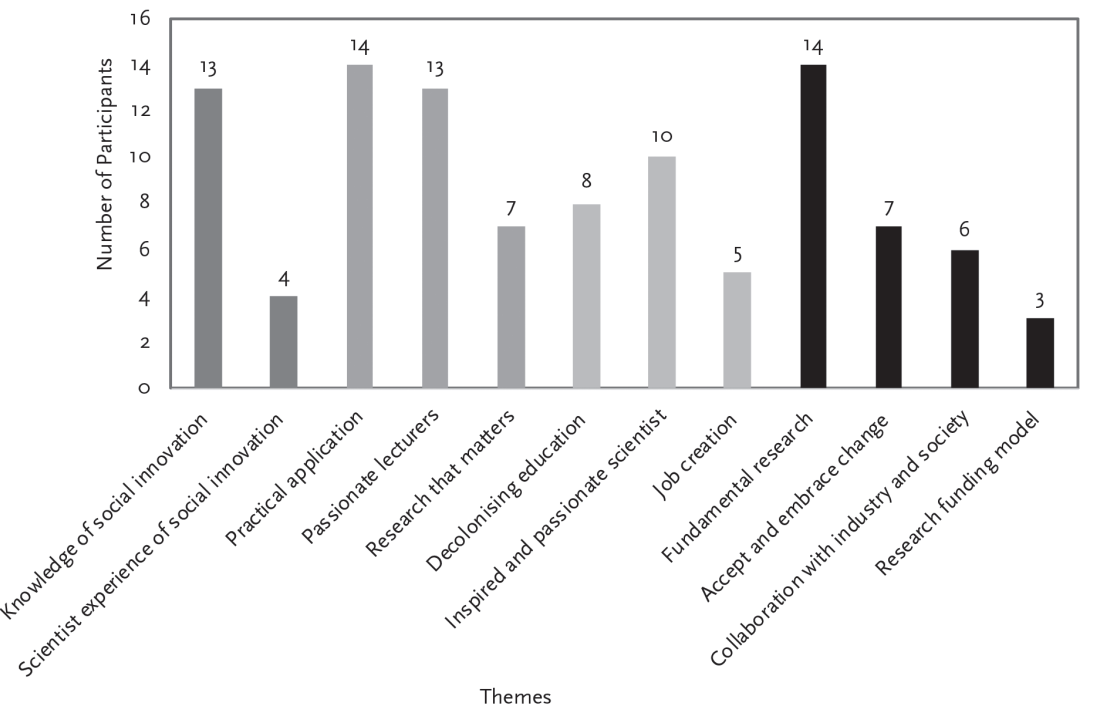

Figure 2: The 12 themes with the total number of participants who identified the themes and the top theme in each category

\section{Understanding of social innovation}

Theme 1: Knowledge of social innovation

Thirteen of the fourteen participants said that they did not know about social innovation during their undergraduate and postgraduate studies.

This was due to many factors, including:

- Lecturers' lack of knowledge on social innovation

- $\quad$ Lack of knowledge on South Africa's current social problems

- Lecturers who are not optimistic and passionate about their communities

- Lecturers that focus only on fundamental issues

- Lecturers that have no vision beyond the chemistry laboratory

- Research which is not driven by societal issues

One participant commented on lecturers' lack of knowledge on social innovation as follows:

"I don't know where this idea of social innovation goes when it comes to academics. Because I wonder how many academics will even understand the concept of social innovation, just the understanding of social innovation. Because if they do not understand the concept, it is unlikely that they will introduce it into their curriculum." - Dr M

Although many participants were of the view that social innovation is a 'new topic', it was defined by Taylor (I970) in the seventies as a practice-led field where people do things in a new way rather than learning about them academically. Because the definition of social innovation varies in different environments, its practice may look and feel different (Blodgett et al., 20I5).

These findings imply that much needs to be done to create awareness and understanding of social innovation. The suggestions made by the participants to achieve this are partially supported by Caulier-Grice, Davies, Patrick, and Norman (20I2), who propose the following common features and core elements of social innovation:

- Novelty: Social innovations need to be new in some way.

- From ideas to implementation: Social innovation is concerned with the practical application or implementation of a new idea.

- Meets a social need: It should be designed to meet a social need.

- Effectiveness: Social innovation should be more effective than existing solutions.

- Enhances society's capacity to act: The process of social innovation enhances society's capacity to act.

While many of the participants were involved in outreach programmes and community projects during their university education, only a few participated in projects which had a social innovation aspect. According to Preston, Ogenchuk, and Nsiah (20I4), the most meaningful and powerful impact of social innovation is often the personal transformative changes that occur in participants in such programmes. The study participants suggested that university leadership should present on-going workshops to raise awareness of social innovation as well as the social challenges currently facing South Africa. They added that South Africans should consciously seek to become part of the solutions to these problems.

\section{Content on social innovation}

Theme 3: Practical application

Tomlinson (20I7) notes that, while the world is changing rapidly, undergraduate degrees have not changed much. All I4 participants agreed that the undergraduate chemical science degree lacks practical application as it is still based purely on the fundamentals of science. The comment by Dr B emphasises this:

"... a lot oflecturers mostly just focus on the textbook content and there is minimum appreciation of the application side on what you can use this knowledge in your society which I think is a pity" - Dr B

However, examples were cited of specific lecturers including aspects of social innovation in their teaching. Mr G, a PhD student, gave an example 
of such a project in chemistry. His passion and excitement shone through when he spoke about his experience of doing scientific work that matters:

"Even the reports that came out of that practice you could see that people were passionate about what they did because they had to think outside the box" - Mr G

He added that projects like this should be replicated as knowing that they can be part of the solution gives scientists a sense of belonging in their community.

The participants were asked if there was social innovation content in the curricula of their chemical science degrees. The findings showed that these curricula lack practical application, which is the core element of social innovation. The literature confirms that the South African education system, especially in terms of basic and higher education, has been considered inadequate in terms of social and economic development (Spaull, 20I3). While HEIs have processes in place for regular curriculum renewal and such processes are usually in line with each institution's mission and profile, social innovation does not seem to be a focus area. Instead, the social innovation identified in universities appears to be a mainly 'tick box' activity undertaken by a few people through outreach programmes and community initiatives.

There is general agreement that the current chemical science curriculum does not enable scientists to come up with innovative solutions to address some of South Africa's current social challenges. An effective chemistry curriculum should be driven by the country's needs, the institution and programme's mission, discipline standards, and business partners' needs. In order to ensure that core skills and knowledge are covered, key stakeholders should be involved in curriculum development.

Brougham and Haar (20I8) highlight that it may be difficult for academic staff to understand the impact of the rapidly changing workplace on their students' future career prospects when so little has changed in how universities function. The question that arises is, how can students be better prepared for a future that cannot be predicted in a rapidly changing world? Traditional education offers an important foundation for technical knowledge, but given the rapid pace of change, this is not sufficient. Universities do relatively well in translating changes in scientific knowledge into course content, but they do not give equal recognition to significant changes in the demand for skills in the outside world, particularly the societies they operate in, and transform their education programmes accordingly (Fry et al., 2008). The participants suggested that universities should increase applied science research without sacrificing fundamental research and also design research that can address some of the social challenges.

\section{Academic curricula}

Theme 7: Inspired and passionate scientists

Ten of the fourteen participants noted that education in the chemical sciences together with knowledge of social innovation could have a positive impact on their performance as scientists. Skills learned in the field of chemical science and social innovation could help scientists to solve some of the prevailing social challenges. Below are some of the comments made by participants:

"... we all want to make a difference in our communities... by not having social innovation in our education we fall short of being the solution givers" - Ms E

"I would think of the satisfaction it will bring as a PhD student, designing polymer nanofibres that can be used to filter and clean a water system in a township somewhere where people are struggling with poor quality of drinking water." - Dr A

The participants felt inspired and motivated by the possibility of including social innovation in chemical science curricula. However, it was noted that there will always be competing issues for academics. Dr $\mathrm{N}$ indicated:

"... firstly, the academic environment is a cut-throat industry. The pressures of publishing in high-impact factor journals can very easily sidetrack the academics even though they started with good intentions because for you to publish in a high-impact journal it has to be new and it should have never been done before... just that can easily take you away from social innovation" - Dr N

It is clear from the above that the participants agreed on the need for education that makes a difference in communities. However, concerns were expressed about the lack of awareness of social innovation among South African scientists. Moreover, where there is awareness, lack of support compounded by not being taken seriously frustrates scientists and they become demotivated.

The literature shows that science has shaped almost every domain of social life (Núñez Jover and López Cerezo, 2008). This is often labelled as the rise of the knowledge society. However, if science is overwhelmingly shaping society, why should society also not shape science? Why should "own selection of research topics" by scientists remain privileged? Why should society not assert its priorities? The problem may be familiar, but there are new complications that cannot be solved using old formu- 
lae. There is a need for social participation where social transformation is driven by science.

Barriers to the introduction of social innovation

Theme 10: Accepting and embracing change

All the participants indicated that it is very difficult for academics to accept or embrace change. As the comments below indicate, the reasons range from ageing academic staff in charge of chemical science departments to fear of universities losing respect and fear of failure associated with the risk of doing something new.

"Social innovation seems like a very new kind of an approach and universities have a legacy of how they do things ... changing that would need a few people to come together to drive this change"- $\operatorname{Dr} C$

"Our professors are old and they do not want to change. They still have the same mark sheet that was handwritten more than 30 years ago because that is what they know works and they are not willing to try something new even though outside we have different challenges." - Mr G

All the participants expressed frustration about the rigid structures of academia, with some expressing hope that change will come from young, up-and-coming academics. This is of concern because it suggests that until the older generation exits academic institutions, social innovation will not be introduced in chemical science curricula.

Although South African universities have undergone structural changes and mergers to promote equity, quality, development, efficiency, and effectiveness (Hay and Fourie, 2002), major transformation is required to create a new identity as inclusive and equitable institutions (Mabokela, 2003) and to transform their academic curricula.

While the study identified five main barriers to the introduction of social innovation in the field of chemical sciences, two common threads emerged. The first is a lack of the information required to develop, implement, and measure social innovation. This is exacerbated by a lack of general awareness of social innovation.

The second thread is academics' reluctance to embrace change, which could be caused by many reasons. Butler (I997) characterised learning as "a disturbing and uncomfortable process", but suggested that being uncomfortable is a necessary aspect of learning. If learning is to be transformative, there must be moments when the participants are unsettled, challenged, and questioned.
Integrated chemical science degree

The participants were asked if they thought a combined chemical science and social innovation degree would have a significant effect on the careers of chemical scientists and what such effects might be. Twelve of the fourteen participants agreed that a combined degree might benefit South Africa. However, they raised different issues relating to combined degrees. Some stated that it would enable scientists to adopt a holistic approach when it comes to applying their skills in business and communities. However, most importantly, they indicated that it would create many opportunities; for example, entrepreneurial skills where people start thinking about how they can be employers rather than employees.

However, although they concurred that combination degrees offer significant advantages, some participants felt that South Africa is not ready for this due to inequality in education, and that combined degrees would only benefit a few. Below are some of the participants' inputs.

"I have been trained as a chemical scientist and as soon as I step out of the university walls I am confronted with how do I convert what I have learned into something of commercial business ... if you do not have those business skills you are immediately on the back foot" - Dr N

"Just thinking now in my current work, I have a handle on the science part but I am grappling with the business side of things ... you do not understand how and why certain decisions are made and why we can't continue with certain projects." - Dr B

Asked what kind of combined degree would interest them and benefit their communities, the majority suggested those set out in Figure 3. The most popular combined degree among the participants was the combination of chemical science with business management and social innovation. This fits with the World Economic Forum's (20I6) observation that entrepreneurial skills are essential in the modern world. The current generation needs to learn new ways of working and this can be achieved by offering them opportunities to shape their own future (Rainie and Anderson, 20I7). This is especially true of those that will be starting their own businesses. For others, these skills and perspectives will be used to change the way that the organisation that employs them operates.

Some participants stated that a supportive framework for SMMEs is required to grow the South African economy. Thus, it would be of benefit to incorporate business management into any degree. Nevertheless, some participants felt that South Africa is not ready for 'prestige' degrees, as literacy levels remain low and the unemployment rate is very high. 


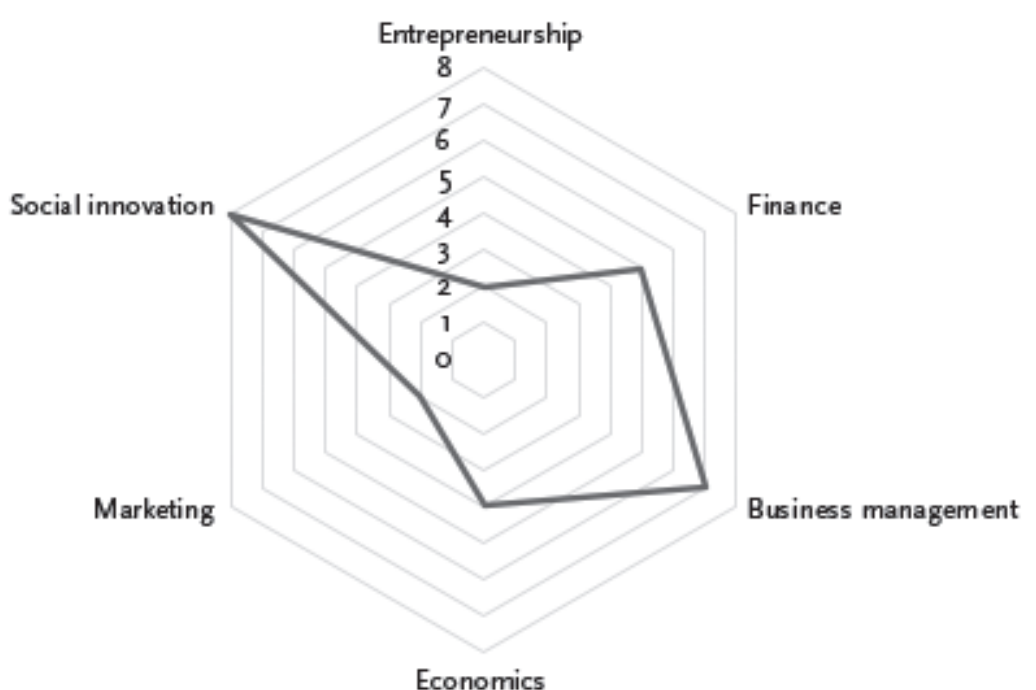

Figure 3: Suggested subjects to be combined with chemical science

The literature identifies combined degrees as a way to develop new competencies to address the skills needs of modern economies. However, de Villiers Scheepers et al. (20I8) note that it is difficult for universities to prepare students for an uncertain future. Will traditional teaching methods and courses still exist or will they become part of a diverse learning environment? (Fry et al., 2008). While there is no simple answer to these questions, as with any complex challenge, universities will need to embrace new ways of working to remain relevant.

Windeløv-Lidzélius (20I8) points to the need to rethink the role of the lecturer as well as what happens in the classroom and the relevant academic methods. This implies that academic institutions should start co-creating education with students (Bergmark and Westman, 20I6). On the other hand, Davey et al. (2018) emphasise that academic models need to shift from teaching to facilitating and leading through social innovation.

\section{Conclusions and recommendations}

The findings of this study point to the need to incorporate social innovation into chemical science curricula and that this will benefit the South African economy. Many of the issues identified as barriers to the implementation of social innovation are daunting, but could be addressed by academics if they are willing to change. The participants noted that chemical scientists need more than just a chemical science qualification to remain competitive in any industry. They also expressed concern about the future of scientists, as there is no longer a need for 'specialised' scientists. It is clear that much needs to be done to increase knowledge and understanding of what social innovation is. There was general agreement that the current chemical science curriculum does not enable scientists to come up with innovative solutions to address some of South Africa's current social challenges. The curriculum is still largely based on fundamental teaching that does not translate into practical application for the betterment of society. It was also apparent that the chemical scientists that participated in this study want education that makes a difference in the communities that they come from.

Based on these findings, it is recommended that South African universities should promote specific academic competencies, especially in the field of chemical science. These should include social innovation in order to enable the development of sustainable models that ensure consistent community engagement and the necessary societal change.

An area of concern is the reluctance to embrace change among both HEIs and their academic staff. It is imperative that universities abandon this attitude and identify opportunities to build a prosperous society. Failure to do so runs the risk of them becoming obsolete.

One of the study's key findings is the need to create awareness of social innovation and the social challenges that are facing South Africa among HEIs. Senior academic leadership should drive awareness campaigns on these issues. They should also encourage faculties and departments to introduce social innovation in their curricula and research. The government has a significant role to play in enabling this through engaging with research funding bodies to make social innovation part of their requirements for research funding.

Combination degrees were identified as a mechanism to produce scientists who adopt a holistic view in applying their skills in business and communities. Most importantly, such degrees could advance entrepreneurial skills whereby people start thinking about how they can be employers rather than employees.

To the best of our knowledge, this is the first empirical study on chemical scientists' perceptions on the interventions required to introduce social innovation to the academic curricula of chemical science degrees in South African universities. It is hoped that the findings will be of practical value to the chemical science industry, academia, chemical science students, and the government, and that they will lay the foundation for future research. 


\section{Practical implications}

This study identified several factors that hinder the introduction of social innovation in the chemical science curriculum. Aspiring chemical scientists could learn from these findings to achieve a realistic view of their careers and to help them plan how they could be better scientists in the future. Established scientists and academics could adapt their approach to their research by incorporating the findings from this study in their research strategy and teaching. Chemical science lecturers are encouraged to expose chemical science students to the findings as part of preparing them not only as scientists, but also as scientists who contribute to the communities they come from.

\section{References}

Aiken, G. (2012). Community Transitions to Low Carbon Futures in the Transition Towns Network (TTN). Geography Compass 6(2), 89-99.

Alden Rivers, B., Armellini, A., Maxwell, R., Allen, S., and Durkin, C. (20I5). Social innovation education: towards a framework for learning design. Higher Education, Skills and Work-Based Learning 5(4), 383-400.

Andion, C., Ronconi, L., Moraes, R. L., Ribeiro Gonsalves, A. K., Serafim, D., and Brum, L. (20I7). Civil society and social innovation in the public sphere: a pragmatic perspective. RAP: Revista Brasileira de Administração Pública 51(3), 369-387

Armendariz, B., and Morduch, J. (2005). The Economics of Microfinance. Cambridge, Mass.: MIT Press.

Department of Arts, Culture, Science and Technology. (I996). White Paper on Science and Technology: Preparing for the 21st century: Dacst.

Atkinson, R., and Da Voudi, S. (2000). The concept of social exclusion in the European Union: context, development and possibilities. Journal of Common Market Studies 38(3), 427-448.

Ayres, R. (I996). Technology, progress and economic growth. European Management Journal 14(6), 562-575.

Baker, S., and Mehmood, A. (20I5). Social innovation and the governance of sustainable places. Local Environment 20(3), 32I-334.

Baxter, R. (2009). The global economic crisis and its impact on South Africa and the country's mining industry. Challenges for monetary policy-makers in emerging markets, I05-II6.

Bergmark, U., and Westman, S. (20I6). Co-creating curriculum in higher education: Promoting democratic values and a multidimensional view on learning. International Journal for Academic Development 21(I), 28-40.

Bersin, J., and Chamorro-Premuzic, T. (20I8). 4 Ways to Create a Learning Culture on Your Team. Harvard Business Reviews.

Blodgett, M. S., Melconian, L. J., and Peterson, J. H. (20I5). Social Enter- prise: Reaffirming Public Purpose Governance through Shared Value. Journal of Business and Securities Law 16, 305.

Bock, B. B. (2016). Rural marginalisation and the role of social innovation; a turn towards exogenous development and rural reconnection. Sociologia Ruralis 56(4), 552-573.

Brock, D. D., and Steiner, S. (2009). Social entrepreneurship education: is it achieving the desired aims? Social Science Research Network.

Brougham, D., and Haar, J. (20I8). Smart technology, artificial intelligence, robotics, and algorithms (STARA): employees' perceptions of our future workplace. Journal of Management and Organization 24(2), 239-257.

Bughin, J., Hazan, E., Lund, S., Dahlström, P., Wiesinger, A., and Subramaniam, A. (20I8). Skill shift: Automation and the future of the workforce. McKinsey Global Institute. McKinsey and Company.

Butler, J. (I997). Excitable speech: a politics of the performative. New York and London: Routledge.

Castleberry, A., and Nolen, A. (2018). Thematic analysis of qualitative research data: Is it as easy as it sounds? Currents in Pharmacy Teaching and Learning 10(6), 807-8I5.

Caulier-Grice, J., Davies, A., Patrick, R., and Norman, W. (2012). Defining social innovation. A deliverable of the project: "The theoretical, empirical and policy foundations for building social innovation in Europe"(TEPSIE), European Commission-7th Framework Programme, Brussels: European Commission, DG Research, 22.

Creswell, J. W., and Poth, C. N. (2016). Qualitative inquiry and research design: Choosing among five approaches. Sage publications.

Cukier, K., and Mayer-Schoenberger, V. (20I3). The rise of big data: How it's changing the way we think about the world. Foreign Affairs 92, 28.

Daud, N. S., Ishak, S. I. D. Abdullah, S., Azmi, A., Ishak, A. S., and Ahmad, Z. (20I8). The Discussion of Social Entrepreneurship: Review of the Literature. Paper presented at the MATEC Web of Conferences.

Davey, T., Meerman, A., Orazbayeva, B., Riedel, M., Galán-Muros, G., Plewa, C., and Eckert, N. (2018). The Future of Universities Thought book: 40 Perspectives on how engaged and entrepreneurial universities will drive growth and shape our knowledge-driven future until 2040. In: Amsterdam: University Industry Innovation Network.

de Villiers Scheepers, M. I., Barnes, R., Clements, M., and Stubbs, A. J. (20I8). Preparing future-ready graduates through experiential entrepreneurship. Education+ Training 60(4), 303-317.

Dees, J. G., and Anderson, B. B. (2006). Framing a theory of social entrepreneurship: Building on two schools of practice and thought. Research on Social Entrepreneurship: Understanding and Contributing to an Emerging Field 1(3), 39-66. 
Field, J. (2000). Lifelong learning and the new educational order. ERIC.

Finegold, D., and Notabartolo, A. S. (20IO). 2Ist century competencies and their impact: An interdisciplinary literature review. In: D. Finegold, M. Gatta, H. Salzman, and S.J. Schurman (eds) Transforming the US workforce development system, pp. I9-56. Champaign, IL: Labor and Employment Relations Association.

Forum, W. E. (20I6). The future of jobs: Employment, skills and workforce strategy for the fourth industrial revolution. Paper presented at the Global Challenge Insight Report, World Economic Forum, Geneva.

Fry, H., Ketteridge, S., and Marshall, S. (2008). A handbook for teaching and learning in higher education: Enhancing academic practice. Routledge.

Galego, D., Amorim, M., Dias, M. F., and Sarmento, M. (20I8a). Barriers of Social Innovation in Academic Curricula. Paper presented at the Conference Proceedings. The Future of Education.

Galego, D., Soto, W., Carrasco, G., Amorim, M., and Ferreira Dias, M. (20I8b). Embedding Social Innovation in Latin America Academic

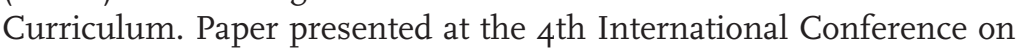
Higher Education Advances (HEAD's8).

Gelb, S. (2006). A South African developmental state: what is possible? Paper presented at the Harold Wolpe Memorial Trust's Tenth Anniversary Colloquium, "Engaging silences and unresolved issues in the political economy of South Africa".

Hart, T. G., Ramoroka, K. H., Jacobs, P. T., and Letty, B. A. (20I5). Revealing the social face of innovation. South African Journal of Science 111(9-10), I-6.

Hay, D., and Fourie, M. (2002). Preparing the way for mergers in South African higher and further education institutions: An investigation into staff perceptions. Higher Education 44(I), II5-I3I.

Kim, J., Rim, S., Han, S., and Park, A. (20I5). Seoul city's social innovation strategy: new models of communication to strengthen citizen engagement. In: A. Nicholls, J. Simon and M. Gabriel (eds) New Frontiers in Social Innovation Research, pp. I70-I9I. London: Palgrave Macmillan.

Kovac, J. (2018). The ethical chemist: Professionalism and ethics in science: Oxford University Press.

Kummitha, R. K. R., and Majumdar, S. (2015). Dynamic curriculum development on social entrepreneurship-A case study of TISS. The International Journal of Management Education 13(3), 260-267.

Kvale, S., and Flick, U. (2007). Doing interviews. London: Sage.

Leedy, P. D., and Ormrod, J. E. (2005). Practical research. Pearson Custom.

Lettice, F., and Parekh, M. (20I0). The social innovation process: themes, challenges and implications for practice. International Journal of Technology Management 51(I), I39-I58.

Levine, A. (20I8). A unique calling: Careers in career development for STEM doctorates. ScienceMag. Retrieved from https://www.sciencemag.org/features/20I8/o8/unique-calling-careers-career-development-stem-doctorates

Leydesdorff, L., and Etzkowitz, H. (200I). The transformation of university-industry-government relations. Electronic Journal of Sociology 5 (4), 338-344.

Littlewood, D., and Holt, D. (2018). Social entrepreneurship in South Africa: Exploring the influence of environment. Business and Society 57(3), 525-56I.

Mabokela, R. O. (2003). "Donkeys of the University": Organizational culture and its impact on South African women administrators. Higher Education 46(2), I29-I45.

Mabotja, L. L. (20I9). Is South African Manufacturing SMMEs Ready for the Fourth Industrial Revolution? Journal of Education and Vocational Research 9(2), 20-26.

Manyaka, S. J. (20I5). Social entrepreneurship: A solution for transforming the disadvantaged community of Nellmapius. Theological Studies 71(3), I-7.

Masri, M. (I986). Chlorinating poultry chiller water: the generation of mutagens and water re-use. Food and Chemical Toxicology 24(9), 923-930.

Matanle, P. (20II). The Great East Japan Earthquake, tsunami, and nuclear meltdown: towards the (re) construction of a safe, sustainable, and compassionate society in Japan's shrinking regions. Local Environment 16(9), 823-847.

Matus, K. J., Clark, W. C., Anastas, P. T., and Zimmerman, J. B. (20I2). Barriers to the implementation of green chemistry in the United States. Environmental science and technology 46(20), 10892-10899.

Maxwell, J. A. (2012). Qualitative research design: An interactive approach (Vol. 4I). Sage publications.

McConnell, I. (20I9). Your PhD Is Not Enough - 7 Articles To Increase Your Business Acumen And Get Hired In Industry. Retrieved from https://cheekyscientist.com/articles-to-increase-your-business-acumen-and-get-hired-in-industry-as-a-phd/

McEachern, M., and Hanson, S. (2008). Socio-geographic perception in the diffusion of innovation: Solar energy technology in Sri Lanka. Energy Policy 36(7), 2578-2590.

McGowan, K., and Westley, F. (20I5). At the root of change: The history of social innovation. In: A. Nicholls, J. Simon, and M. Gabriel (eds) New frontiers in social innovation research, pp. 52-68. London: Palgrave Macmillan.

Melles, G., de Vere, I., and Misic, V. (20II). Socially responsible design: thinking beyond the triple bottom line to socially responsive and sustainable product design. CoDesign 7(3-4), I43-154.

Miles, M. B., Huberman, A. M., and Saldaña, J. (20I4). Qualitative data analysis: A methods sourcebook (3rd ed.). Thousand Oaks, CA: Sage. 
Moore, G. (2004). The Fair Trade movement: parameters, issues and future research. Journal of Business Ethics 53, 73-86.

Moulaert, F., Martinelli, F., González, S., and Swyngedouw, E. (2007). Introduction: Social innovation and governance in European cities: urban development between path dependency and radical innovation. European Urban and Regional Studies 14(3), 195-209.

Mújica-Paz, H., Valdez-Fragoso, A., Samson, C. T., Welti-Chanes, J., and Torres, J. A. (20II). High-pressure processing technologies for the pasteurization and sterilization of foods. Food and Bioprocess Technology 4(6), 969.

Mulder, I., Bohle, W., Boshomane, M., Morris, C., Tempelman, H., and Velthausz, D. (2008). Real-world innovation in rural South Africa. The Electronic Journal for Virtual Organizations and Networks 10 (Special issue on Living Labs), I4.

Murray, R., Mulgan, G., and Caulier-Grice, J. (2008). How to Innovate: The tools for social innovation. Retrieved April, 28, 2012 from https:// youngfoundation.org/wp-content/uploads/20I2/ıO/How-to-innovate-the-tools-for-social-innovation.pdf

Nancarrow, S. A., Booth, A., Ariss, S., Smith, T., Enderby, P., and Roots, A. (20I3). Ten principles of good interdisciplinary team work. Human resources for Health 11(I), I9.

Núñez Jover, J., and López Cerezo, J. A. (2008). Technological innovation as social innovation: Science, technology, and the rise of STS studies in Cuba. Science, Technology, and Human Values 33(6), 707-729.

O’Byrne, L., Miller, M., Douse, C., Venkatesh, R., and Kapucu, N. (20I4). Social Innovation in the Public Sector: The Case of Seoul Metropolitan Government. Journal of Economic and Social Studies 4(I),53-7I.

Omarjee, L. (2019). SA unemployment rate jumps to $29 \%$, the worst since 2008. Retrieved from https://www.fin24.com/Economy/just-in-saunemployment-rate-jumps-to-29-the-worst-since-2008-20I90730. https://www.fin24.com/Economy/just-in-sa-unemployment-ratejumps-to-29-the-worst-since-2008-20190730

Omona, J. (2013). Sampling in qualitative research: Improving the quality of research outcomes in higher education. Makerere Journal of Higher Education 4(2), I69-I85.

Oosthuizen, M. (20I6). Why South Africa can't deliver on the social contract set out in its constitution. The Conversation, 2I November.

Patel, L., and Hochfeld, T. (2013). Developmental social work in South Africa: Translating policy into practice. International Social Work 56(5), 690-704.

Patton, M. Q. (2002). Qualitative research and evaluation methods. Thousand Oakes CA: Sage.

Phillips, W., Lee, H., Ghobadian, A., O’Regan, N., and James, P. (20I5).
Social innovation and social entrepreneurship: A systematic review. Group and Organization Management 40(3), 428-46I.

Phills, J. A., Deiglmeier, K., and Miller, D. T. (2008). Rediscovering social innovation. Stanford Social Innovation Review 6(4), 34-43.

Prasad, S.C. (20I6). Innovating at the margins: The System of Rice Intensification in India and transformative social innovation. Ecology and Society 21(4), 7

Preston, J. P., Ogenchuk, M. J., and Nsiah, J. K. (20I4). Peer mentorship and transformational learning: PhD student experiences. Canadian Journal of Higher Education 44(I), 52-68.

Rainie, L., and Anderson, J. (20I7). The Future of Jobs and Jobs Training. Pew Research Center.

Raynolds, L., Murray, D., and Wilkinson, J. (2007). Fair Trade: The Challenges of Transforming Globalization. New York, NY: Colorado State University.

Reddy, V., Bhorat, H., Powell, M., Visser, M., and Arends, F. (20I6). Skills supply and demand in South Africa (Commissioned by the Department of Higher Education and Training (DHET), Labour Market Intelligence Partnership (LMIP), September).

Rexhepi, G., Kurtishi, S., and Bexheti, G. (2013). Corporate social responsibility (CSR) and innovation - the drivers of business growth? Procedia - Social and Behavioral Sciences 75, 532-54I.

Rodriguez, A., and Rodriguez, Y. (20I5). Metaphors for today's leadership: VUCA world, millennial and "Cloud Leaders". Journal of Management Development 34, 854-866.

Ruben, B. D. (2018). Quality in higher education. Routledge.

Santosham, M. (2002). Oral rehydration therapy: reverse transfer of technology. Archives of Pediatrics and Adolescent Medicine 156(I2), II77-II79.

Sekliuckiene, J., and Kisielius, E. (20I5). Development of social entrepreneurship initiatives: a theoretical framework. Procedia - Social and Behavioral Sciences 213, IOI5-IOI9.

Sharma, Y. (20I7). How do you prepare students for an unknowable future. University World News, I4 October.

Shuzi, Y. (2002). Integration of Science and Humanity - Eucational Innovation [J]. Researches in Medical Education 1.China National Knowledge Infrastucture. Retrieved from en.cnki.com.cn.

Sinclair, S., and Baglioni, S. (20I4). Social innovation and social policy promises and risks. Social Policy and Society 13(3), 469-476.

Spaull, N. (20I3). South Africa's education crisis: The quality of education in South Africa I994-20II, pp. I-65. Johannesburg: Centre for Development and Enterprise.

Sporn, B. (I999). Towards more adaptive universities: Trends of institutional reform in Europe. Higher Education in Europe 24(I), 23-33. 
Sulla, V., and Zikhali, P. (20I8). Overcoming poverty and inequality in South Africa: An assessment of drivers, constraints and opportunities. International Bank for Reconstruction and Development/The World Bank, Washington. Retrieved from http://documents.worldbank.org/ curated/en/53048I52I735906534/pdf/I2452I-REV-OUOSouth-AfricaPoverty-and-Inequality-Assessment-Report-20I8-FINAL-WEB.pdf.

Swilling, M. (2016). Africa's game changers and the catalysts of social and system innovation. Ecology and Society 21(I), 37.

Taylor, J. B. (I970). Introducing social innovation. The Journal of Applied Behavioral Science 6(1), 69-77.

Tencer, D. (20I7). 85\% of jobs that will exist in 2030 haven't been invented yet. In: Dell. Huff Post, I4 July.

Tomlinson, M. (20I7). Student perceptions of themselves as 'consumers' of higher education. British Journal of Sociology of Education 38(4), 450-467.

Tremblay, K., Lalancette, D., and Roseveare, D. (2012). Assessment of higher education learning outcomes: Feasibility study report, volume 1 design and implementation. Paris, France: Organisation for Economic Co-operation and Development.

Van der Have, R. P., and Rubalcaba, L. (20I6). Social innovation research: An emerging area of innovation studies? Research Policy 45(9), I923-I935.

Van Niekerk, A., and Viviers, W. (20I4). Promoting sustainable economic growth in South Africa through the export of low-carbon environmental goods. South African Journal of Economic and Management Sciences $17(4), 427-439$.

Walker, B. H., and Salt, D. (2006). Resilience thinking: sustaining ecosystems and people in a changing world. Washington D.C.: Island Press.

Walwyn, D., and Cloete, L. (20I8). Draft White Paper on Science, Technology and Innovation neglects to prioritise issues of performance and human capability. South African Journal of Science 114(II-I2), I-6.

Windeløv-Lidzélius, C. (20I8). The School as a Living Lab - The Case of Kaospilot. In: M. Dezuanni, M. Foth, K.M. Mallan, H.E. Hughes and R. Osborne. Digital Participation through Social Living Labs, pp. 77-96. Elsevier.

Zweig, D., Fung, C., and Han, D. (2008). Redefining the brain drain: China's diaspora option. Science Technology and Society 13(I), I-33. https://doi.org/I0.II77\%2F097I72I80701300I0I 